$1-1-1965$

\title{
West Virginia's new housing and management system for raising broilers
}
A. D. Longhouse
J. O. Heishman
C. J. Cunningham

Follow this and additional works at: https://researchrepository.wvu.edu/ wv_agricultural_and_forestry_experiment_station_bulletins

\section{Digital Commons Citation}

Longhouse, A. D.; Heishman, J. O.; and Cunningham, C. J., "West Virginia's new housing and management system for raising broilers" (1965). West Virginia Agricultural and Forestry Experiment Station Bulletins. 508.

https://researchrepository.wvu.edu/wv_agricultural_and_forestry_experiment_station_bulletins/472 @ WVU. It has been accepted for inclusion in West Virginia Agricultural and Forestry Experiment Station Bulletins by an authorized administrator of The Research Repository @ WVU. For more information, please contact ian.harmon@mail.wvu.edu. 
West Virginia University Libraries

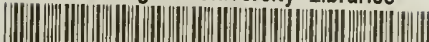

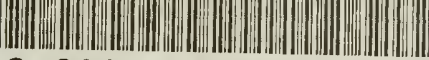

308021008961379 
Digitized by the Internet Archive in 2010 with funding from

Lyrasis Members and Sloan Foundation 


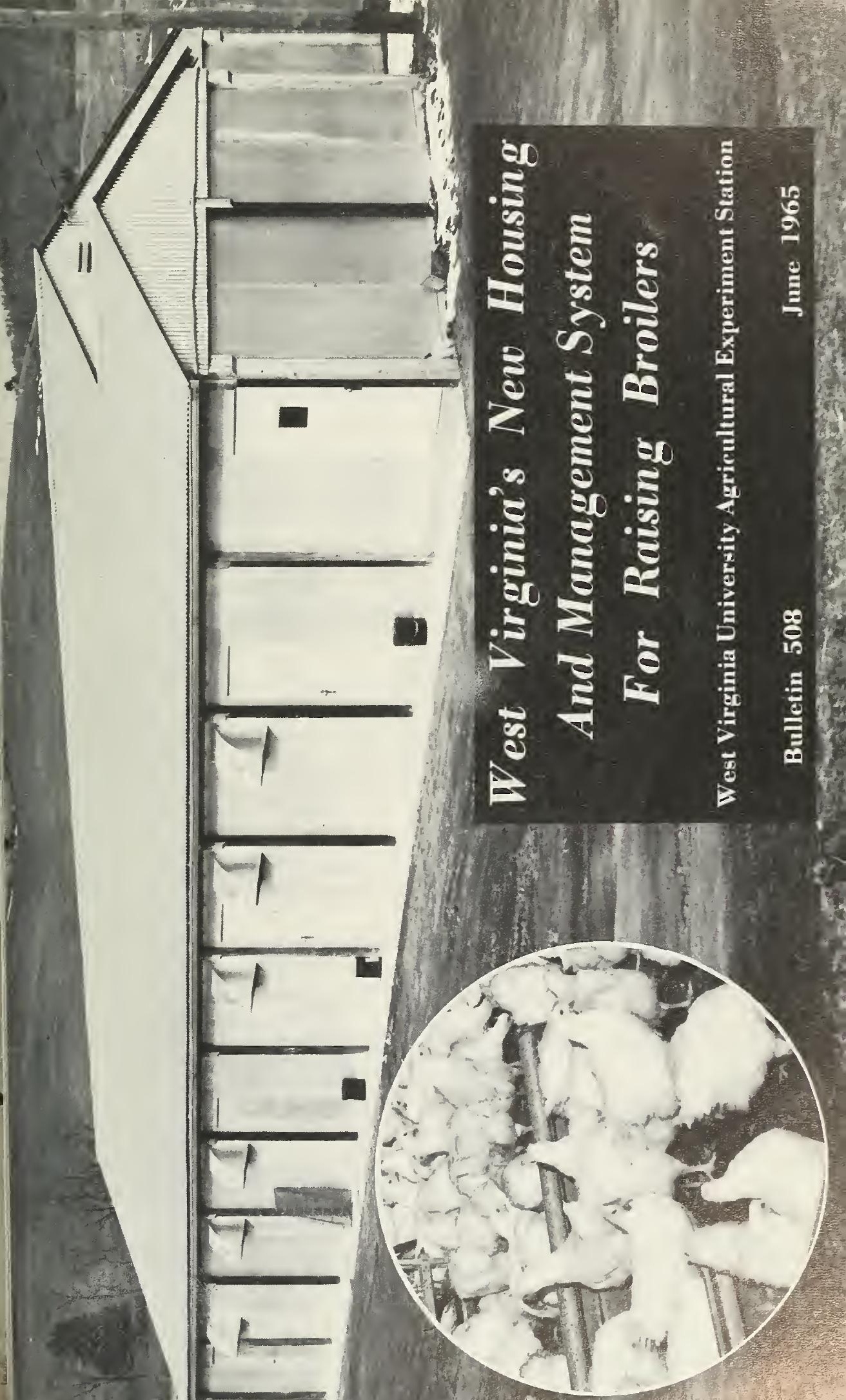




\title{
THE AUTHORS
}

A. D. Longhouse is Professor and Chairman of Agricultural Engineering, College of Agriculture, Forestry, and Home Economics and Agricultural Engineer in the Experiment Station; J. O. Heishman is Associate Station Animal Pathologist, Reymann Memorial Farms Sub-station; and C. J. Cunningham is Station Animal Jushandman in charge of Reymann Memorial Farms.

\author{
WEST V'IRGINia UNIVERSITY \\ Agricultural Experiment Station \\ College of Agriculture, Forestry, and Home Economics
}

A. H. V'anLandingham, Director

MORGaNTOWN 


\section{Summary}

After nearly two years of research involving 20 broods, it appears feasible to raise broilers of different ages in the same building provided airtight partitions are used between each age group and each pen has its own feeding, watering, and ventilation system.

The management system described in this bulletin produces as many broilers annually with only two-thirds the floor space required of the "all in-all out" method. This system utilizes buildings, equipment, labor, and capital more efficiently than present methods.

Size of broiler (age) determines the space required. One-day to three-week-old chicks have $1 / 3 \mathrm{ft}^{2}$ in the starting pen; chicks from 4 weeks to 6 weeks, $12 \mathrm{ft}^{2}$ in the intermediate pen; and birds from 7 weeks

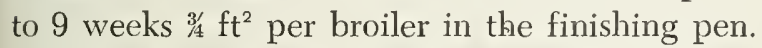

Heat losses due to conduction and infiltration are held to a minimum by insulation and tight house construction.

Minimum air movement to control respired moisture only reduces brooding costs.

Broilers may be moved from pen to pen without producing undue stress. Live weights, feed efficiency, and mortality compare favorably with present methods of raising broilers. The cost of brooding is considerably less. A brood is sold every 28 days. Thirteen broods are raised annually.

Only two respiratory disease outbreaks have occurred in the finishing pen. No medication or vaccination practices are employed.

\section{Summary of Advantages}

Can raise $33 \%$ more broilers annually on the same floor area than with the "all in-all out" method.

Requires less brooding equipment and uses it more efficiently per pound of broiler produced.

More uniform demand for labor and feed because of three age groups in the house.

Capital turnover occurs 13 instead of 4 or 5 times each year.

\section{Summary of Disadvantages}

Danger of respiratory diseases.

More careful management practices are required.

Increases cost of housing per square feet (separate ventilation systems, concrete floors-with drains, air-tight partitions). 


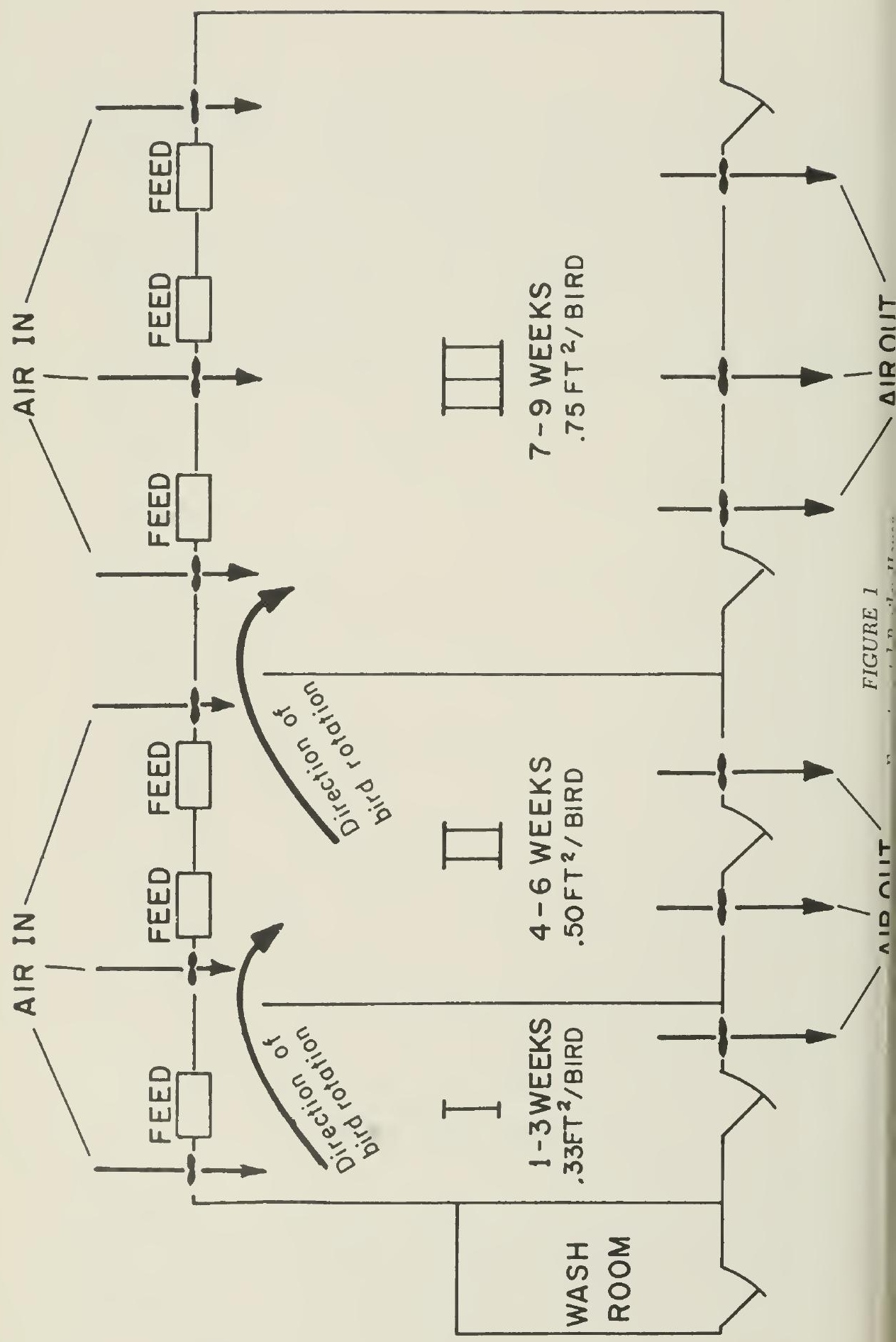




\section{West Virginia's New Housing And Management System For Raising Broilers}

\section{A. D. Longhouse, J. O. Heishman and C. J. Cunningham}

Poultrymen, veterinarians, and agricultural engineers in the West Virginia University Agricultural Experiment Station have initiated a program which may bring about more efficient use of buildings, equipment, labor and capital in broiler production."

The present method of producing broilers, the "all in-all out" method, utilizes buildings, equipment, and labor inefficiently. One-day-old chicks are placed under hovers in a house until fully grown and sold at 8-9 weeks of age. The house is then cleaned and made ready for the next brood. This method produces five batches a year at best, usually fewer.

At the beginning of the brooding period, chicks need less than one-third the space they will need at nine weeks of age. Heat lost by conduction and infiltration is high during the early part of the brooding period. This adds greatly to the cost of brooding.

Under this system, brooders and other equipment are used only part of the time. For example, if the broiler producer has his own incubator, he only operates it at one-third of its yearly capacity.

If the broiler producer has only one house, feed, labor, and capital requirements fluctuate greatly and thus made good management difficult.

To control diseases, the broiler producer has been forced to use the "all in-all out" system. However, introduction of antibiotics and new techniques in management aid in control of diseases; engineering has brought about changes in building construction, including new materials, mechanical ventilation, and lighting. This knowledge should be coordinated and used to bring about greater efficiency in broiler production.

\section{The Management Program}

The method of brooding requires a house with three pens (Figure 1). The starting pen provides $0.33 \mathrm{ft}^{2} / \mathrm{bird}$, the intermediate pen $0.5 \mathrm{ft}^{2} / \mathrm{bird}$, and the finishing pen provides $0.75 \mathrm{ft}^{2} /$ bird. Each pen has its own ventilation system, brooding equipment, lights, water, and feed. The partitions between pens are airtight. The only access to each pen is from the outside except when the chickens are transferred between pens.

*Research was conducted at the Reymann Memorial Farms Sub-station, Wardensville, West Virginia. 


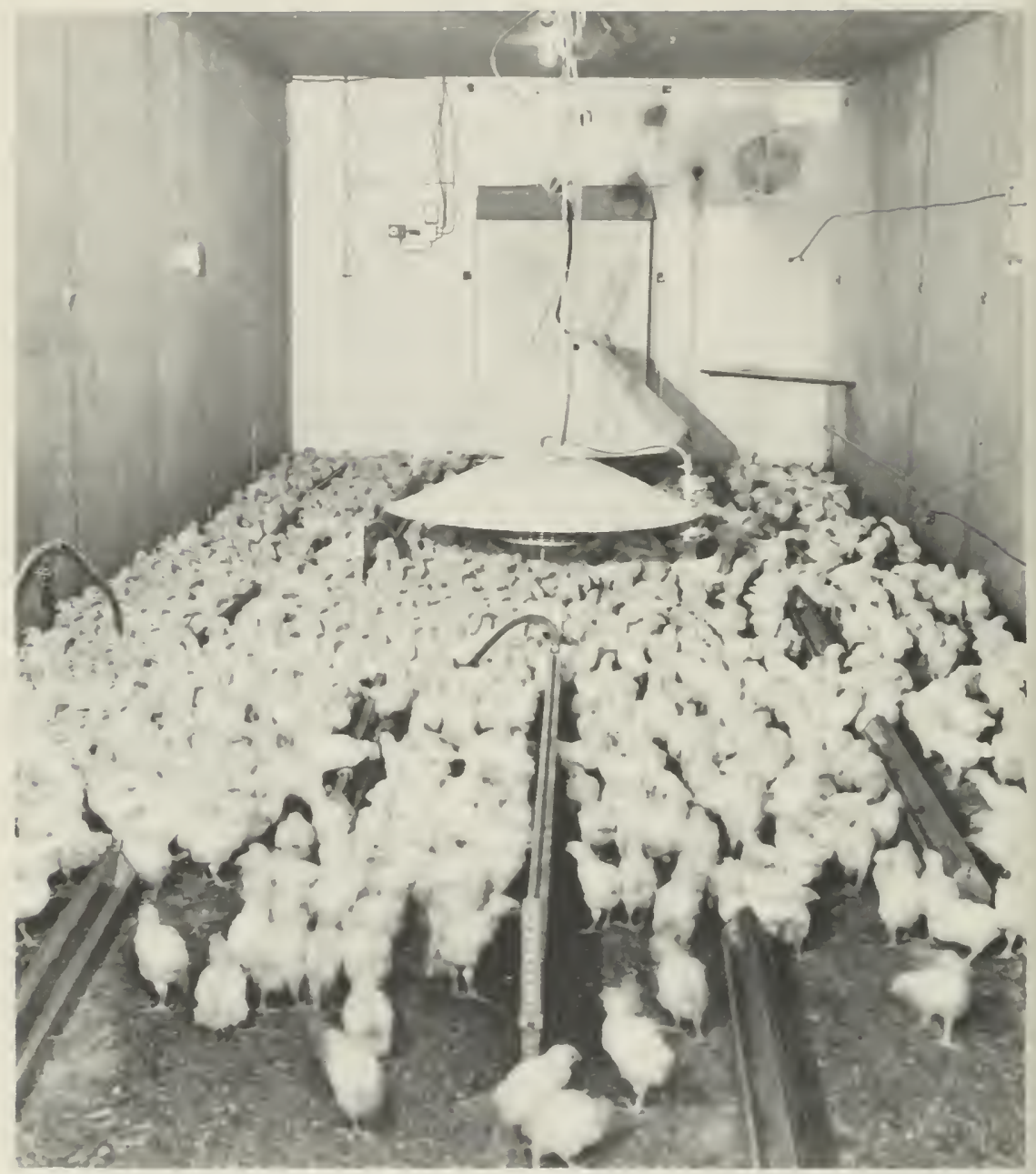

FIGURE 2. Three-week-old broilers in the starting pen.

Chicks are kept in the starting pen, Figure 2, from the time they are one-day-old until they are three weeks of age. They are then transferred to the intermediate pen, Figure 3, through an opening 16 inches by 4 feet at one end of the partition. This opening proved to be inadequate, so another opening, 4 feet by 4 feet, was made in the wall, Figure 4. This new opening facilitated transfer of the birds. It would be better yet to provide an opening 4 feet high and $\delta$ feet wide. The birds may be more easily transferred to the next room if the door in the partition is opened several hours before the actual transfer takes place. After the transfer is completed, the opening is sealed airtight again. 


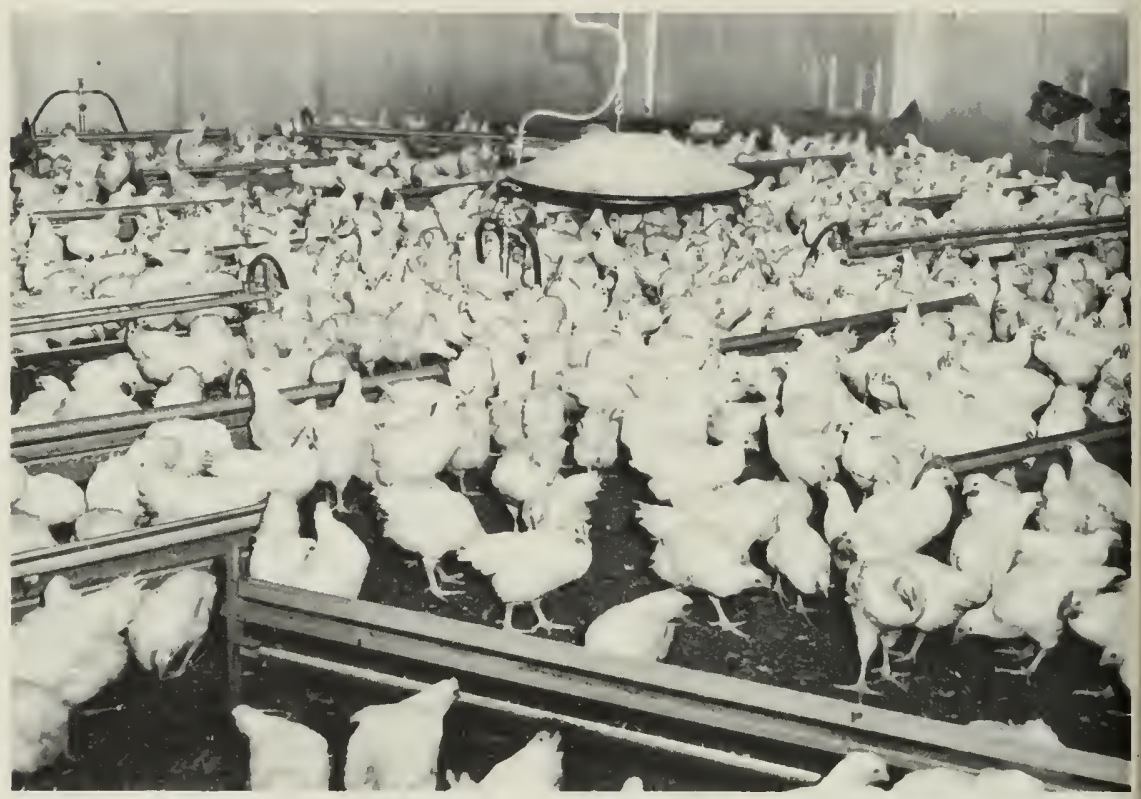

FIGURE 5. Broilers 7 weeks old in the finishing pen will be sold when they are 9 wecks old.

The birds are held in the intermediate pen for three weeks. Thereafter they are transferred through a similar opening in the partition to the finishing pen, Figure 5, where they are kept another three weeks and then sold.

As soon as a pen is emptied of a brood, it is cleaned and washed thoroughly and is not used for one week, Figure 6. This period of idleness helps control diseases and adds flexibility to an otherwise rigid program. No medication or vaccination is used to control disease. It has not been necessary to practice debeaking in order to control cannibalism in this system of management for producing broilers.

A new brood is placed in the starting pen every 28 days and a batch is sold out of the finishing pen every 28 days. A maximum of 13 batches may be moved through the house annually.

More than the usual precautions are taken to prevent introduction of diseases. Each pen has its own feed supply. Feed is brought to the building and emptied into special hoppers in the outside wall, Figure 7. The caretaker removes the feed through small sliding doors in the feed hoppers. He must first care for the younger birds and then for older ones. If he re-enters a pen with younger birds, changes in outer garments and footwear are made before entering. Visitors are not permitted inside the building. 
The building is windowless except for small observation windows in the doors, which are usually covered. (Electric lights provide approximately $1 / 2$-foot-candles during the day and $114-$ foot candles during the night.) There are two 25-watt lamps in the starting pen, four 25-watt lamps in the intermediate pen, and six 25-watt lamps in the finishing pen. This furnishes about 0.7 foot-candles directly under the lamp at the floor and 0.2 foot-candles midway between lamps.

Initial brooder temperature in the starting pen is $95^{\circ} \mathrm{F}$, and room temperature is $90^{\circ} \mathrm{F}$. In the intermediate pen, the brooder is started at $75^{\circ} \mathrm{F}$, and the room temperature is $70^{\circ} \mathrm{F}$. Usually no brooder is needed in the finishing pen except when the outside temperature remains well below $32^{\circ} \mathrm{F}$. A room temperature of $60-70^{\circ}$ is desired in this pen.

Outside design temperatures are based on the average for the coldest' and warmest ${ }^{2}$ months of the year.

\section{The Broiler House}

A new windowless building 32 feet $\times 72$ feet was constructed for this experiment. The capacity of each pen is 1,200 birds or 3,600 for the entire house.

Insulation consisted of 3 inches of fiberglass batts in the wall and 5 inches in the ceiling.

The overall " $U$ " value for the building is calculated to be 0.10 $\mathrm{Btu} / \mathrm{ft}^{2}-\mathrm{hr} .-^{\circ} \mathrm{F}$. Square creosoted posts are used to support the gable roof and permit the use of non-bearing panels in the exterior and interior walls. Braced rafters provide clear span construction. Thus, there is considerable flexibility should future changes be necessary.

The 8 feet by 8 feet outside wall panels have an outer covering of .029-inch aluminum, 3-inch fiberglass insulation, 4-mil polyethylene vapor barrier, and one-fourth-inch exterior grade plywood inside covering. The one-fourth-inch plywood ceiling supports 5 inches of insulation and a 4-mil polyethylene vapor barrier. All joints are sealed with tape and the entire surface covered with two coats of aluminum paint to aid thorough cleaning. The concrete floors slope to drains in the center of each pen to facilitate cleaning after each batch. All equipment is washed and new litter is provided for each batch of chickens.

\footnotetext{
$1 \mathrm{January}$ is the coldest month of the year in West Virginia. The average mean temperature at Wardensville is $34^{\circ} \mathrm{F}$, and the average relative humidity at noon is about 70 per cent. (U.S. Weather Bureau Temperature Data.)

${ }^{2}$ High outside temperature during the warmest month of the year is not considered detrimental to broiler production in West Virginia. The average mean temperature August at Wardensville is $73^{\circ}$ F. (U.S. Weather Bureau Temperature Data.)
} 


\section{Ventilation}

Each pen has its own intake fan (pressurized) ventilation system. All fans are on the windward side of the house and all exhaust openings are on the opposite side (Figure 1). Ventilation in each pen is regulated by thermostat and timer.

A continuous flow of air is desirable so as to remove respired moisture as rapidly as it is produced. The minimum rates in the starting, intermediate, and finishing pens are 100, 250, and $500 \mathrm{cfm}$, (cubic feet oer minute), respectively. Additional air is provided by fans controlled y thermostats. The second fan in the starting pen has a maximum capacity of $500 \mathrm{cfm}$. An additional fan in the intermediate pen delivers L,500 cfm. Two fans in the finishing pen each deliver $1,500 \mathrm{cfm}$.

Ventilation must be limited to only the amount needed to remove noisture in pens where heat is added. This usually will provide a satisactory inside environment. Additional air only removes heat, thus ncreasing the cost of brooding.

\section{Results}

The first group of broiler chicks was placed in the starting pen uly 23, 1963. As of April 1, 1965, 20 broods have been sold.

Mortality losses have been low. Excessive heat from the brooding quipment caused high room temperatures and low humidity for the irst two broods. This has been corrected so as to hold room temperaures within the desired limits.

The first eleven broods were from Station flocks fed unpelletized eed, most of which was produced on the Station Farm (Table 1).

The feed conversion ratio of 2.38 and live weights of 3.22 pounds t nine weeks were satisfactory for Station-grown stock fed unpelletized eed (Table 1).

The live weight and feed conversion at nine weeks improved when ommercial broiler stock was fed pelletized broiler rations after the irst three weeks (Table 2). For these broods, mortality was 2.12 er cent, nine-week average weight was 3.65 pounds, and the feed onversion was 2.21 .

The first serious outbreak of disease occurred during the eighth reek in Brood Number 16. (Refer to the discussion on diseases for dditional information.) Significantly, the disease did not appear in he next three broods while in the finishing pen, nor did it spread to ie other pens.

The data in Tables 1 and 2 show that the 20 broods reared in the ouse averaged 3.42 pounds with a feed conversion ratio of 2.31 at 
TABLE 1

Live Weight, Feed Conversion, and Mortality at Nine Weeks for Station-Bred Stock Fed Unpelletized Station-Grown Feed

\begin{tabular}{ccccc}
\hline \hline $\begin{array}{c}\text { Brood } \\
\text { Number }\end{array}$ & $\begin{array}{c}\text { Number } \\
\text { Chicks } \\
\text { Started }\end{array}$ & $\begin{array}{c}\text { Mortality } \\
\text { (Per Cent) }\end{array}$ & $\begin{array}{c}\text { Average } \\
\text { Weight } \\
\text { (Lbs. 9 Wks.) }\end{array}$ & $\begin{array}{c}\text { Feed } \\
\text { Conversion } \\
\text { (Lss. of feed/lb } \\
\text { of broiler) }\end{array}$ \\
\hline 1 & 1,049 & 3.33 & 3.37 & 2.34 \\
2 & 1,012 & 2.76 & 3.27 & 2.42 \\
3 & 1,255 & 2.47 & 3.18 & 2.37 \\
4 & 1,514 & 1.91 & 3.25 & 2.28 \\
5 & 1,290 & 0.93 & 3.38 & 2.58 \\
6 & 1,150 & 1.27 & 3.30 & 2.44 \\
7 & 1,200 & 1.25 & 3.21 & 2.41 \\
8 & 1,061 & 1.19 & 3.32 & 2.34 \\
9 & 1,361 & 0.95 & 3.07 & 2.37 \\
10 & 982 & 2.65 & 3.17 & 2.36 \\
11 & 1,440 & 0.90 & 2.94 & 2.25 \\
\hline Average & 1,210 & 1.78 & 3.22 & 2.38 \\
\hline
\end{tabular}

nine weeks of age. Mortality ranged from 0.90 per cent to 3.76 per cent with an average of 1.89 per cent for 20 broods.

During the 21 months the house has been in operation several type: of brooders and sources of heat have been used (Table 3 ). The tight well-insulated house using a minimum of ventilation to control humidit: has kept heat losses at a minimum. During the first summer, one oi (kerosene) brooder provided too much heat for the 1,200 chicks in the starting pen. In the winter months, one oil brooder was not sufficien so some supplemental heat was provided by an infrared electric brooder For the second summer, an electric space heater provided enough hea in the starting pen. This was supplemented by the infrared electri brooder in the fall months. Beginning with Brood Number 17 (10/13/64) new bottled gas brooders were installed. During the coldest periods one bottled gas brooder in the starting pen does not provide enougl heat so supplemental heat is provided by the infrared electric brooder

Brooding costs shown in Table 3 vary considerably with the seasor of the year and the source of heat used. Costs for heat were based or 10.8 cents per gallon for oil, 1.5 cents per KWH of electricity, and 2 cents per gallon for bottled gas. The cost for brooding with oil appear less than for bottled gas; however, some labor is involved in keepin the oil tanks filled.

The average cost per bird for brooding is 0.71 cents, which is quite satisfactory. 
TABLE 2

Live Weight, Feed Conversion, and Mortality at Nine Weeks for Commercial Broiler Stock Fed Pelletized Broiler Rations*

\begin{tabular}{lcccc}
\hline \hline $\begin{array}{c}\text { Brood } \\
\text { Number }\end{array}$ & $\begin{array}{c}\text { Number } \\
\text { Chicks } \\
\text { Started }\end{array}$ & $\begin{array}{c}\text { Mortality } \\
\text { (Per Cent) }\end{array}$ & $\begin{array}{c}\text { Average } \\
\text { Weight } \\
\text { (Lbs. 9 Wks. }\end{array}$ & $\begin{array}{c}\text { Feed } \\
\text { Conversion } \\
\text { (Lbs. of feed/lb. } \\
\text { of broiler) }\end{array}$ \\
\hline $12 \uparrow$ & 1,200 & 2.04 & 3.07 & 2.20 \\
13 & 1,200 & 2.45 & 3.69 & 2.09 \\
14 & 1,200 & 1.88 & 3.78 & 2.12 \\
15 & 1,200 & 2.29 & 3.94 & 2.15 \\
$16+$ & 1,200 & 3.76 & 3.81 & 2.27 \\
17 & 1,200 & 1.80 & 3.82 & 2.24 \\
$18 \|$ & 1,200 & 1.06 & 3.44 & 2.31 \\
19 & 1,200 & 2.04 & 3.75 & 2.26 \\
20 & 1,200 & 1.72 & 3.59 & 2.23 \\
\hline Average & 1,200 & 2.12 & 3.65 & 2.21 \\
\hline
\end{tabular}

Chicks one day to three weeks in starting pen are fed mash not pellets.

Commercial broiler stock fed unpelletized Station-grown feed.

A respiratory disease (CRD) developed during the seventh week.

Station-bred stock fed commercial pelletized rations.

\section{Disease}

The problem of controlling the spread of disease, particularly from older to younger birds, has been the major reason why researchers, oultrymen, Extension personnel, and others have recommended that only birds of one age be kept on a farm at a time. Therefore, if some conomically feasible means of overcoming the disease hazard could be levised, this problem could be eliminated.

In the course of the work reported in this bulletin, covering a period of twenty-one months, there have been twenty separate broods of chicks eared to nine weeks of age in the same building. In order to accomplish his, two ages of chickens were in the building at all times and three tges one-fourth of the time.

Chicks for the first eleven broods were produced on the Station (Table 4) and were from known Mycoplasma gallisepticum (MG)* nfected breeder stock. Chicks for broods twelve through twenty, with he exception of brood eighteen, were obtained from a commercial source. Brood eighteen chicks were produced at the Station and were from known MG-free breeders.

Vaccination or medication, except a coccidostat at a preventative level continuously in the feed, were not used in the course of this work.

Frequently referred to by producers as PPLO. 


\section{TABLE 3}

Brooding Costs Vary with the Season and Sources of Heat

\begin{tabular}{|c|c|c|c|c|}
\hline \multirow[b]{2}{*}{$\begin{array}{l}\text { Brood } \\
\text { Number }\end{array}$} & \multirow{2}{*}{$\begin{array}{l}\text { Fuel Cost } \\
\text { Per Chick } \\
\text { (Cents) }\end{array}$} & \multirow[b]{2}{*}{ Source of Heat } & \multicolumn{2}{|c|}{ SEASON } \\
\hline & & & $\begin{array}{l}\text { Date } \\
\text { Started }\end{array}$ & $\begin{array}{l}\text { Date } \\
\text { Sold } \\
\end{array}$ \\
\hline 1 & .54 & Oil, only & $7-23-63$ & $9-23-63$ \\
\hline 2 & .40 & Oil, only & $8-20-63$ & $10-21-63$ \\
\hline 3 & .45 & Oil, only & $9-17-64$ & $11-18-63$ \\
\hline 4 & .32 & Oil, only & $10-15-63$ & $12-12-63$ \\
\hline 5 & 1.00 & Oil, only & $11-12-63$ & $1-14-64$ \\
\hline 6 & .64 & Oil, only & $12-10-63$ & $2-10-61$ \\
\hline 7 & .78 & Oil \& Electricity ${ }^{\circ}$ & 1- 7-64 & 3- $9-64$ \\
\hline 8 & .65 & Oil \& Electricity ${ }^{\circ}$ & $2-4-64$ & 4- $4-64$ \\
\hline 9 & .32 & Oil \& Electricity ${ }^{\circ}$ & 3- 3-64 & 5- $4-64$ \\
\hline 10 & .46 & Oil \& Electricity ${ }^{\circ}$ & $3-31-64$ & $6-2-61$ \\
\hline 11 & .28 & Oil \& Electricity ${ }^{\circ}$ & $4-28-64$ & $6-29-6+$ \\
\hline 12 & .39 & Electricity $\nmid$ & $5-26-64$ & $7-27-64$ \\
\hline 13 & .46 & Electricity $\nmid$ & $6-23-64$ & $8-24-6$ \\
\hline 14 & .65 & Electricity $\nmid$ & $7-21-64$ & $9-22-6=$ \\
\hline 15 & .18 & Electricity $f$ & $8-18-64$ & $10-20-6$ \\
\hline 16 & .09 & Electricity ${ }^{\circ}$ & $9-15-64$ & $11-17-6$ \\
\hline 17 & 1.23 & Gas, bottled & $10-13-64$ & $12-14-6$ \\
\hline 18 & 1.22 & Gas, bottled & $11-10-64$ & $1-12-6=$ \\
\hline 19 & 1.86 & Gas, bottled & $12-8-64$ & 2- $9-6 i$ \\
\hline 20 & $2.33 \ddagger$ & Gas, bottled & $1-5-65$ & $3-8-6$ \\
\hline
\end{tabular}

Average $\quad 0.71$

*Infrared.

$\mp$ Industrial space heater.

$\ddagger$ Had some difficulty with the brooder thermostats in pen 2

Diseases, especially contagious ones, have not been troublesom in producing these twenty broods of broilers under this system of housing and management, despite the fact that seven of the twenty broods wert harboring varying amounts of $\mathrm{MG}$, as indicated by laboratory examina tions. Signs of respiratory disease were evident in only Brood Sixtee and Brood Twenty. In Brood Sixteen, a sneeze or cough developed a eight weeks and the laboratory examination revealed that $\$ 5$ per cen of the birds were infected with $\mathrm{MG}$. The development of chronic respiratory disease (CRD) late in the brooding period resulted in : slightly higher mortality (Table 4 ) and slight decrease in average weigh and feed efficiency (Table 2 ). It is interesting that the three subsequen broods $(17,18$, and 19) had no sign of respiratory disease and wert found negative for MG on laboratory examination. Although no appar 
ent spread of MG occurred between broods it should be kept in mind that MG is egg transmitted and is less likely to spread from flock to flock than the virus of Newcastle Disease or infectious bronchitis. Results of a laboratory examination of a sample of the chicks for Brood Twenty on the day they were delivered revealed the presence of MG. Slight respiratory signs were noticed when this brood was 7 weeks old and these signs continued until the birds were sold. Although the respiratory disease did not become severe enough to cause increased mortality ( Table 4), it apparently did cause a lower average weight of the birds at 9 weeks (Table 2 ).

Of the 24,375 chicks started, 461 , or 1.89 per cent, died during the brooding period (Table 4). Of the total mortality, 283 chicks, or 61.5 per cent, died during the first three weeks, and of this number, 189 shicks, or 66.8 per cent, died during the first week. Navel infection or visceral gout were the chief disease conditions that caused the early mortality.

TABLE 4

Mortality by Broods and Periods

\begin{tabular}{cccccc}
\hline $\begin{array}{c}\text { Brood } \\
\text { Number }\end{array}$ & $\begin{array}{c}\text { Chicks } \\
\text { Started }\end{array}$ & $\begin{array}{c}\text { Total } \\
\text { Mortality }\end{array}$ & $\begin{array}{c}\text { First } \\
\text { 3 Weeks }\end{array}$ & $\begin{array}{c}\text { Second } \\
\text { 3 Weeks }\end{array}$ & $\begin{array}{c}\text { Third } \\
\text { 3 Weeks }\end{array}$ \\
\hline 1 & 1,049 & 36 & 28 & 5 & 3 \\
2 & 1,012 & 28 & 15 & 6 & 7 \\
3 & 1,255 & 31 & 25 & 3 & 3 \\
4 & 1,514 & 26 & 20 & 3 & 3 \\
5 & 1,290 & 13 & 10 & 2 & 1 \\
6 & 1,150 & 14 & 9 & 1 & 4 \\
7 & 1,200 & 15 & 4 & 0 & 11 \\
8 & 1,061 & 15 & 8 & 4 & 3 \\
9 & 1,361 & 13 & 5 & 1 & 7 \\
10 & 982 & 26 & 15 & 1 & 10 \\
11 & 1,440 & 13 & 6 & 1 & 6 \\
12 & 1,224 & 25 & 22 & 1 & 2 \\
13 & 1,224 & 30 & 14 & 9 & 7 \\
14 & 1,224 & 23 & 13 & 5 & 5 \\
15 & 1,224 & 28 & 17 & 3 & 8 \\
16 & 1,224 & 45 & 16 & 9 & 20 \\
17 & 1,224 & 22 & 14 & 6 & 2 \\
18 & 1,224 & 13 & 8 & 3 & 2 \\
19 & 1,224 & 26 & 19 & 3 & 4 \\
20 & 1,224 & 19 & 15 & 1 & 3 \\
\hline Total & 24,375 & 461 & 283 & 67 & 111 \\
\hline
\end{tabular}


Mortality was comparatively light during the second three-week period (Table 4). Mortality in this period resulted from different causes with no particular condition standing out.

Mortality during the third three-week period represented 24.1 per cent of the total deaths (Table 4). The chief disease conditions encountered in this period were leucosis, and, in the case of Brood Sixteen, CRD.

It is believed that a mortality of 1.89 per cent based on the actual number of chicks started is well within the normal range for the broiler industry as a whole.

Disease control has not proved to be a problem under this system of housing and managing broilers even without the use of disinfectants, vaccines, or medication. However, in view of the fact that a readily contagious disease such as Newcastle Disease or infectious bronchitis has not been encountered thus far, it is not possible to state what the results would be if such outbreak were to occur. This point will be investigated in the near future. 

